(7)

\title{
Determinants of Terrorism and Its Impact on Economic Growth: A Panel Study of South Asian Region
}

\author{
${ }^{a}$ Maria Saddiqa, ${ }^{\mathrm{b}}$ Shabana Parveen, ${ }^{\mathrm{c}}$ Sher Ali, ${ }^{\mathrm{d}}$ Waqas Ahmed \\ ${ }^{a}$ PhD Scholar, Department of Economics, Hazara University, Mansehra, Pakistan \\ Email: sweet_maria92@yahoo.com \\ ${ }^{\mathrm{b}}$ Assistant Professor, Department of Economics, Hazara University, Mansehra, Pakistan \\ Email: shabana_economist@yahoo.com \\ ${ }^{c}$ Assistant Professor, Department of Economics, Islamia College, Peshawar, Pakistan \\ Email: drali@icp.edu.pk \\ d Lecturer, Government post Graduate College, Mansehra, Pakistan \\ Email: malik.waqas9390@gmail.com
}

\begin{tabular}{|c|c|}
\hline ARTICLE DETAILS & ABSTRACT \\
\hline History: & \multirow{10}{*}{$\begin{array}{l}\text { The objective of the study is to examine the key determinants of } \\
\text { Terrorism and its Impact on Economic Growth in case of South Asian } \\
\text { Region. Panel data is used for the period of 1985-2018 for selected south } \\
\text { Asian countries. Terrorism affected adversely most of the world's } \\
\text { regions since the start of the 1980s. The main issues which are faced by } \\
\text { these countries are related to political or economic aspects like poverty, } \\
\text { inflation, unemployment and repression. In present study we used the } \\
\text { role of macroeconomic factors of terrorism. The study comprised of } \\
\text { balance panel data and employed Fixed Effect Model to analyze the } \\
\text { determinants of terrorism in such a way that characteristics of each } \\
\text { country can be taken into account. The findings of the study suggest that } \\
\text { higher literacy rate determines terrorism, as confirmed by many studies, } \\
\text { because the more people are educated the more knowledge they may } \\
\text { have for making plans or strategies similarly, unemployment is not } \\
\text { leading terrorism showing that more the people involved in terrorism } \\
\text { are employed or experienced. A terrorist act destroys the infrastructure; } \\
\text { people are afraid to move for their work in a terrorized society these } \\
\text { results in low production and makes demand greater than supply } \\
\text { consequently high inflation rate so economy has to pay higher economic } \\
\text { cost in any form. }\end{array}$} \\
\hline Accepted 25 May 2020 & \\
\hline Available Online 15 June 2020 & \\
\hline Кey & \\
\hline Terrorism Determinants, & \\
\hline Economic Growth, Panel Data & \\
\hline Technique & \\
\hline JEL & \\
\hline D72, & \\
\hline DOI: $10.47067 /$ reads.v6i2.219 & \\
\hline
\end{tabular}

(C) 2020 The authors. Published by SPCRD Global Publishing. This is an open access article under the Creative Commons Attribution-

NonCommercial 4.0

Corresponding author's email address: drali@icp.edu.pk

\section{Introduction}

Terrorism was a limited phenomenon of Middle East and south Asia before the terrible event of 


\section{Review of Economics and Development Studies, Vol. 6 (2) 2020, 413-423}

9/11/2001 when the terrorist attack on the world trade centre and pentagon shocked the global economy and influenced the socio-economic and geo-political ground of the world. Since this horrible event of September 11, 2001, terrorism has become a familiar word for every one with negative conception (Kellner, 2004).

There are different types of cost of terrorism having their different impacts, like terrorism cost associated with law and order enhance the cost of military, police and judicial. When the aid and loans are given to a country in the result of a terrorism disaster then the cost takes form of influence on the political decision and thus becomes a challenge. Social cost is in link with standard of living, health, education etc. which affects the poor sector of a country on a large scale. Economic cost is related to the negative effect of terrorism on the growth enhancing programs of a country. It discourages foreign and local investors, damages infrastructure, deter consumer spending, depreciation of the currency, cause unemployment and thus hamper economic growth. For instance Pakistan is under severe terrorist since mid 9o's. The average annual average growth rate was significantly above 5\% till mid 9o's and since then this rate has declined to below 4\% (calculations based on statistics reported in World Development Indicators, 2012).

There can be numerous reasons of low economic growth; terrorism is one of them. Terrorism, no doubt hampers economic growth by lowering foreign and local investment. But the more important issue is to look at the factors that cause terrorism in which low growth rate, inflation, inequality, unemployment, low literacy level, high population growth rate, ethnic and religious polarization, political structure, military expenditures, poverty, income inequality, regime durability, size of government, past incidences, trade openness, human development index, foreign aid etc are included (Ismail and Amjad, 2014). As If a country does not have a developed established economic system or is unable to fulfill the demand of its country men then it would cause negative effects on social, economic indicators of that country which may indulge people into terrorism activities. Deterioration in investment, unemployment, inflation, inequality and poverty may intensify the feelings of anger, animosity which would be satisfied by participating in terrorist incidents.

The studies like Lawrence et.al. (1983), Bloomberg et al. (2002), James and David (2003), Quan and Drew (2004), Sharma Kishor (2006) and Carlos et al. (2007) showed in their results that it is low economic growth, democracy, high population growth rate, unemployment and inequality that lead to terrorism. However studies like Freytag Andreas et al. (2011), Krisztina et al. (2010) and, Caruso and Schneider (2010) had shown that high economic growth can also cause terrorism. As increase in GDP growth in a country will improve the living and education standard thus humanizing the basic necessities thus there will be more consideration on technology and competition which leads to use of the technology and advancement in a wrong way, in order to compete over against their competitors.

Since 1985 South Asia is suffering from high level of terrorist attacks; in these context 16,942 incidences of terrorism took place in South Asia which is almost $1 / 4$ of the world wide terrorist attacks (Global Terrorism Database). Table 1.1 gives the summary of number of terrorist in the South Asia along with other parts of the world since last twenty five years.

Table-1: Numbers of Terrorist Attacks in South Asia As Well As Other Parts of the World

\begin{tabular}{|l|l|l|}
\hline Years & South Asia & Rest of the World \\
\hline $1985-1990$ & $3,115(14.89 \%)$ & 20,918 \\
\hline $1991-1995$ & $2,658(10.11 \%)$ & 26296 \\
\hline $1996-2000$ & $1,851(18.57 \%)$ & 9968 \\
\hline
\end{tabular}


Review of Economics and Development Studies, Vol. 6 (2) 2020, 413-423

\begin{tabular}{|l|l|l|}
\hline $2001-2005$ & $1,879(27.25 \%)$ & 6896 \\
\hline $2006-2010$ & $7,439(37.25 \%)$ & 19,972 \\
\hline $2011---2015$ & $16,155(28.09 \%)$ & 57502 \\
\hline $2016---2018$ & $16,466(48.31 \%)$ & 34087 \\
\hline
\end{tabular}

Table 1.1 depicts that between 1985 and 1990, 20,918 incidence were occurred worldwide of which $14.89 \%$ incidence took place South Asia. This percentage though declined during 1991 - 1995, but thereafter it is continuously increasing. During 2006-2010 more than 37 percent of terrorist attacks took place in South Asia region. While 2016-2018 its ratio increase very rapidly i.e 48\%.

These statistics clearly show that South Asia is one of the largest victims of terrorism. In spite of being highly victim origin of terrorism hardly a few empirical analysis have been conducted to address this issue. Nasir et al. (2011) work is notable that highlighted the determinants of terrorism by using the data of 1972 to 2006 for south Asian countries. They found that both economic and political structure of a country leads to terrorism as high income inequality and deprivation in the political rights along with civil liberties are the major determinants of terrorism. Moreover they found high literacy level is positively associated with terrorism. The study by Nasir et al. (2011) covers the period till 2006. The most severe period in terms of terrorist attacks is from 2006 to 2010 (as shown in Table 1.1). The present study attempts to analyze the factors behind terrorism in South Asia. We shall extent the period till 2018 and shall also incorporate a few more determinants of terrorism.

This study has a vital significance as it will be a comparative analysis of terrorism situation along with the impact of its on economic growth among four South Asian countries. The study comprises of many sections, such as, After Introduction in first section, review of the related studies is presented in next section. Subsequently Data and variables are explained in section 3. The next section is about methodology and estimation techniques and final section is about Results and discussions and conclusion.

Alan and Jatika (2002) analyzed the data of terrorist attack against Israel between 70 and late 8 os by conducting the public opinion poll in Palestine. The public opinion showed that the rich and highly educated people are in favor of terrorist attacks against Israel. On the same lines, Bloomberg et al. (2002) investigated the importance of economic variables in determining the terrorist attacks by using the data of 127 countries for the years from 1968 to 1991. They found that high income and democratic countries experience more number of terrorist incidents, they also found that contraction in economic activity also leads to terrorist activities by bringing business cycles consequently enhancement in terrorist activities. In the same manner, Carlos (2003) investigated the relation of deterrence effect, political effect and economic effects on terrorism for Spain. The analyses were carried out from 1968 to 2000. He found that there is no significant influence of deterrence on terrorism but political effects significantly influence terrorism whereas economic effect on terrorism was unseen. Similarly, James and Todd (2004) quantified the relationship between economic growth and civil war by using the data of 84 countries for the period of 1961-1995 and reveled through results that poverty, political instability, barren terrain and large population are strong predictor for civil war as compared to ethnic and religious diversity.

Quan and Drew (2004) estimated the effect of economic globalization on the number of transnational terrorist incidence within countries through the data of 112 countries from 1975 to 1997. They found that trade; direct investment and portfolio investment have an indirect positive 


\section{Review of Economics and Development Studies, Vol. 6 (2) 2020, 413-423}

effect on transnational terrorist incidence but the economic development and the trading partners of a country reduce the number of terrorist incidence of that country. In short trade and foreign direct investment promote economic development thus it has a negative indirect effect on transnational terrorism.

In another study of Quan (2005) assessed the effect of democracy on transnational terrorism incidents for the data spanning form 1975 to 1997 for 119 countries. He found that democratic regime and economic development reduces the incidence of terrorism in a country, while income inequality and incidence of terrorism in past were positively associated with terrorism. Kishor (2006), by using the data of country Nepal for the years from 1974 to 2002 estimated the relationship between civil war and economic development. He found that development failure gives birth to civil war as once a country failed to achieve development it raise unemployment, poverty, rural-urban inequality which leads to frustration and resentment among youngster and provoke them for beginning of the civil war. Similarly, Peter et al. (2006) estimated the relationship of economic and political freedom with terrorism incidents for the data of 121 countries for the years 1996-2002. They found that political rights and civil liberty are negatively linked with terrorism incidents, whereas inequality, economic growth, poverty and education do not affect terrorism. Atin and William (2007) demonstrated ethnic polarization as a determinant of terrorism. The analysis was based on 18 countries from 1982 to 1997. They found that high ethnic polarization leads to emergence of terrorism in those countries where there is a lack of economic freedom, thus roots of terrorism are economic rather than ethnic. Likewise Claude (2007) was a good empirical investigation at the micro level, in which he investigated the way through which terrorism is in linked with education and poverty. He used the data between the late 1980s and 2002. Result showed that higher education and improvement in standard of living is positively associated with terrorism activities whereas the probabilities of getting married reduce the chance to be engaged in terrorist activities.

Carlos et al. (2007) analyzed the terrorist attack in Africa against US citizens during 1978 to 2002. The study revealed that terrorist attacks are persistent and perpetuated in those countries which are characterized by poverty, low level of political and economic freedom. Correspondingly Thomas et al. (2009) identified the links between domestic terrorism and the rate of real GDP per capita growth in order to find either economic growth swayed the terrorism or terrorism affects growth negatively, they used the data of 7 Western European countries for 1950-2004. They conclude that economic performance plays a role for determining the terrorist violence for some countries but terrorism never influences economic growth. Andreas et al. (2010) tested in their working paper that poor socio-economic development is favorable or not for terrorism. They used data of five different samples of countries namely all countries, OECD countries, European countries, Islamic countries, Islamic countries excluding oil exporting countries for 1971 to 2005. They found that if countries are developed then they can get the benefits in terms of reduction in terrorism by increasing the opportunity cost of terrorism.

Krisztina et al. (2010) analyzed the determinants of domestic and international terrorism by using panel data set of 159 countries spanning from 1970 to 2007. They showed that GDP per capita, more open and competitive political system and more experiences of domestic conflicts leads to increase in international terrorism. Raul and Friedrich (2010) investigated the socio-economic causes of terrorism and political violence by using the data of 12 countries for 1994-2007. They found that greater the availability of the current economic opportunities for people, lower the chances to be involved in terrorist activities. Moreover they also found that expected future 


\section{Review of Economics and Development Studies, Vol. 6 (2) 2020, 413-423}

economic growth is positively associated with current terrorist activity which has been explained by productivity argument. James (2011) examined the relationship between poverty and terrorism by including a new factor of minority economic discrimination for the data of 172 countries and years from 1970 to 2006. He found out that Economic status is a potential predictor of terrorism; moreover countries having high minority economic discrimination are more likely to face domestic terrorist attack than those countries where there is less minority economic discrimination. Thus minority discrimination is a strong predictor of domestic terrorism. And Clare (2011) examined whether the level of unemployment and higher education is in link with terrorist attacks. The analysis was based on 56 countries for the period 1980 to 2008 . The study found that unemployment and population size are strongly related to terrorism but higher education has no significant relationship with terrorism. Similarly, Nasir et al. (2011) investigated the determinants of terrorism for selected south Asia countries including Pakistan, India, Bangladesh and Sri Lanka. They analysis were based on data from 1972 to 2006 . They found that economic growth has negative and inflation has positive effect on terrorism.

After the above detail discussion this study aimed to trace out the macroeconomic determinants of terrorism affect economic growth in the selected south Asian countries. In our analysis we analyze GDP per capita, inflation, literacy rate, freedom and unemployment rate as a determinant of terrorism for Pakistan, Bangladesh, India and Sri Lanka for the period of 1985 to 2018.

\section{Methodology}

The present study is based on selected countries of South Asia (Bangladesh, India, Pakistan and Sri Lanka). The reason of selecting this region is that it is included in those regions which have been victim of terrorism in different periods. For instance, during $2005-2010$ more than one-third of the global terrorist attacks were confined to South Asia region.

A South Asian region consists of Afghanistan, Bangladesh, Bhutan, India, Maldives, Nepal, Pakistan and Sri Lanka, our study is restricted to Bangladesh, India, Pakistan and Sri Lanka. The reason of skipping other countries is non-availability of data. Among the skipped countries, Afghanistan is highly victim of terrorism, but data on other variables is not available. As far as period of analysis is concerned our data set is consisting upon the years spanning from 1985 to 2018 because in these years south Asia faced terrorism at high level.

\subsection{Model Specification and Variables Definition}

\subsubsection{The Model}

Since the objective of this study is to explore the role of major macroeconomic variables in determining the magnitude of terrorism. In specific our interest is to analyze how per capita GDP, inflation, Freedom, literacy and unemployment affect terrorism. We are assuming in our model that the term fixed effect is because of the difference in the cross sectional units rather than time. The specified model is as follows for determinants of terrorism

$$
T_{i t}=\sum_{i=1}^{4} \propto i(D i)+\beta_{1} P G D P_{i t}+\beta_{2} I N F_{i t}+\beta_{3} F R E_{i t}+\beta_{4} L I T_{i t}+\beta_{5} U N_{i t}+u_{i t}
$$

The subscript $i$ is shows the cross sectional unit and $t$ denotes the time.

Where,

$D i$ = Dummy variable for each cross-sectional unit, 
$P G D P=$ Per capita GDP constant measured in US \$,

$I N F=$ GDP deflator as a proxy of inflation rate,

$F R E=$ Level of political freedom in a country,

$L I T=$ Literacy rate,

$U N=$ Unemployment rate.

\subsubsection{Variables Description and Data Sources}

Variables description and data sources are presented in the following table.

Table-2: Data Description (Variables' Definition and Data Source)

\begin{tabular}{|l|l|}
\hline Variable & Data Source \\
\hline $\begin{array}{l}\text { Terrorist Incidents } \\
\text { Number of Terrorist Incidents In a Year }\end{array}$ & $\begin{array}{l}\text { Global } \\
\text { Terrorism } \\
\text { Data Base } \\
\text { (GTD) }\end{array}$ \\
\hline $\begin{array}{l}\text { Per Capita GDP } \\
\text { GDP Per Capita (constant 2000 US \$) }\end{array}$ & $\begin{array}{l}\text { World } \\
\text { Development } \\
\text { Indicator } \\
\text { (WDI) }\end{array}$ \\
\hline $\begin{array}{l}\text { Inflation } \\
\text { GDP Deflator }\end{array}$ & $\begin{array}{l}\text { World } \\
\text { Development } \\
\text { Indictors(WDI) }\end{array}$ \\
\hline $\begin{array}{l}\text { Freedom } \\
\text { Average of Political Rights and Civil Liberties }\end{array}$ & $\begin{array}{l}\text { Freedom } \\
\text { House(FH) }\end{array}$ \\
\hline $\begin{array}{l}\text { Literacy Rate } \\
\text { Percentage of the population above 15 who can read or write }\end{array}$ & $\begin{array}{l}\text { Miscellaneous } \\
\text { Data Source }\end{array}$ \\
\hline $\begin{array}{l}\text { Unemployment Rate } \\
\text { Percentage of Unemployed Labor Force }\end{array}$ & $\begin{array}{l}\text { LABORSTA by } \\
\text { International } \\
\text { labor } \\
\text { organization } \\
\text { and Economic } \\
\text { survey of } \\
\text { Pakistan }\end{array}$ \\
\hline
\end{tabular}

\subsubsection{Estimation Technique}

This section elaborates the empirical model of the study for analyzing the determinants of terrorism. Our study is based on four cross-sectional units and 34 years. Therefore it is a balanced 


\section{Review of Economics and Development Studies, Vol. 6 (2) 2020, 413-423}

panel data. Panel data estimation can be analyzed by depending upon the assumption regarding the intercept term, slope coefficients and the error terms. As it will be wrong to assume that all countries are having same characteristics therefore we incorporate the cross country deterministic effect in the analysis through the varying intercept term.

Now there are two ways to incorporate deterministic effects in the model either in form of Random Effects Model (REM) or Fixed effects Model (FEM).Fixed effects model allows the intercept term to vary across cross sectional units in order to capture the differences among cross sectional units because each cross sectional unit has different characteristics. In fixed effect model intercept may vary across time so that time effect can be captured. More over both cross sectional units and time effect can also be allowed to vary intercept term. These differences are taken into account by using the dummy variables in the FEM model, after inclusion of the dummy variable fixed effect model is known as least square dummy variable model.

In Random effect model, the selected cross sectional units are taken randomly from a large set of population in which all cross sectional units have common mean value for intercept. The differences in the individual intercept term of each cross sectional units from this constant mean value are expressed in error term.

In short we can say that in fixed effect model each cross sectional unit have its own fixed intercept and in random effect model mean value of all the cross sectional units is common intercept for all cross sectional units.

The preference of fixed effect model over random effect model or random effect model over fixed effect model depends on the followings:

- Random effect model will be most appropriate when the cross sectional specific units are not correlated with the explanatory variable because the correlation between cross section specific units and explanatory variable makes the random effect model estimator biased which will not be biased in case of fixed effect model.

- In fixed effect model, the least square dummy variable model can come across with the problem of degree of freedom when the cross sectional units are large in number but random effect model does not have such problem.

- Fixed effect model is preferred over random effect model when the number of time period is larger than number of cross sectional units due to convenience in computation.

- If the cross sectional units are not taken randomly in the sample analysis then fixed effect model is most appropriate. When the cross sectional units are taken randomly then random effect model will be appropriate because the statistical inference of the estimators depends on the cross section units either they are observed or randomly drawings.

We preferred fixed effect model over random effect model because we want to analyze the determinants of terrorism in such a way that characteristics of each country can be taken into account.

\section{Results and Discussion}


Review of Economics and Development Studies, Vol. 6 (2) 2020, 413-423

\subsection{Preliminary Statistics of Variables}

Now we shall discuss the preliminary statistics of each variable. Table 3.2 gives the average of different variable during the period of analysis.

Table-3: Average Statistics of Each Variable (1985 - 2018)

\begin{tabular}{|l|l|l|l|l|}
\hline & Bangladesh & India & Pakistan & $\begin{array}{l}\text { Sri } \\
\text { Lanka }\end{array}$ \\
\hline $\begin{array}{l}\text { Terrorism } \\
\text { incidence }\end{array}$ & 27.42 & 219.57 & 171.07 & 98.73 \\
\hline Per capita GDP & 360.58 & 436.09 & 515.56 & 802.23 \\
\hline Inflation & 5.57 & 7.37 & 9.67 & 9.58 \\
\hline Freedom & 3.71 & 2.78 & 4.71 & 3.80 \\
\hline $\begin{array}{l}\text { Unemployment } \\
\text { rate }\end{array}$ & 2.87 & 3.70 & 5.58 & 5.25 \\
\hline Literacy rate & 54.32 & 56.75 & 43.44 & 91.75 \\
\hline
\end{tabular}

According to table 3.2 terrorist incidents remained high in India among all the south Asian countries about 219.57 on average whereas Pakistan faced 171.07 terrorist incidents as compared to India which is less, however there were less terrorist incidents in Sri Lanka and Bangladesh. The statistics of per capita GDP reveal that on average Sri Lanka had highest per capita GDP, whereas Bangladesh has the lowest per capita GDP.

Inflation and unemployment rate were high in Pakistan among our all selected south Asian countries with an average inflation rate of 9.67 and 5.58 unemployment rate. Bangladesh had the lowest inflation as well as unemployment rate among these four south Asian countries.

Since 1985 to 2018 India was the most democratic country and Pakistan was the least, as the freedom rate was 2.78 in India and 4.71 in Pakistan and when we look at the average literacy rate we found that Sri Lanka is the most literate society and Pakistan is at bottom of the list.

\subsection{Results of the Fixed Effect Model}

The results of our empirical analysis are presented in Table 5.1. All the coefficients are Significant except per capita GDP, the coefficient's significance is showing that inflation, repression, literacy rate and unemployment rate is determining terrorism positively or negatively. If there is 1 unit change in per capita GDP it will bring 0.06 unit decline in terrorism incidence which is not significant because increase in GDP per capita will increase the share of investment, trade openness, government spending and decreases the inflation, unemployment, inequality, and poverty thus less the people use wrong ways for earnings and low incidence of terrorism.

\section{Table-4: Results of the Estimated Model}

\begin{tabular}{|l|llll|}
\hline Variable & Coefficient & Std. Error & t-Statistic & Prob. \\
\hline Per capita GDP & -0.064 & 0.095145 & -0.677864 & 0.4995 \\
Inflation & 10.359 & 2.675462 & 3.872023 & 0.0002 \\
Freedom & -46.524 & 13.60143 & -3.420531 & 0.0009 \\
Literacy rate & 4.457 & 1.077633 & 4.136292 & 0.0001 \\
Unemployment & -15.444 & 7.054014 & -2.189425 & 0.0310
\end{tabular}




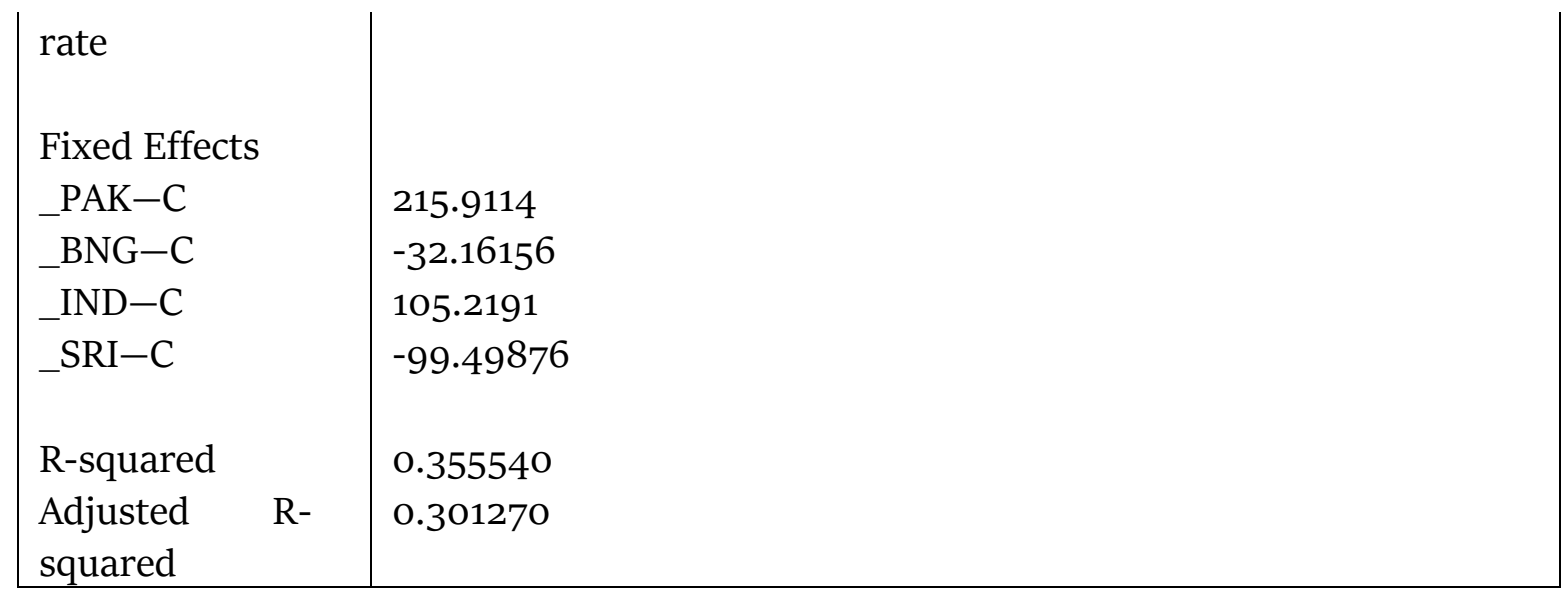

Inflation is positively associated with terrorism incidence significantly. There will be 10.3 units increase in terrorist incidence due to 1 unit change in inflation. Inflation is considered as an important determinant of terrorism because inflation reduces the purchasing power of money and makes a person unable to fulfill his basic needs which open wrong ways of earning in form of involvement in the terrorist activities. Freedom is negatively associated with terrorism incidence showing more the repressive country will be there will be less terrorism incidence in a country. There will be decline in terrorism incidence of about 46.5 units in a country when there would be 1 unit change in repressiveness of a country. According to the results of this data set, repression is favorable for decreasing the terrorism as if there would be dictator ship or autocracy in these countries there will strict check and balance on all type of religious and political group demonstration that may lead to terrorism.

Literacy rate is positively and significantly related to terrorism incidence that 1 unit change in literacy rate will bring 4.45 units increase in terrorism incidence.it is because that literate people are better in handling the targets of a terrorist organization and helpful in making their plans. As far as unemployment is concerned surprisingly unemployment is not predicting terrorism. Terrorist incidence decreases by $\mathbf{1 5 . 4 4}$ units if there occur 1 unit change in unemployment.it is because that a terrorist organization is preferring experienced people over non-experience so that they required less time to be trained as compared to unemployed who have no experience or we can say that most of people those are involved in terrorist incidents are employed or experienced and another reason of employed people to be involved in terrorist activities may be that there salary is not enough to fulfill their family needs so they use their experience or education in wrong way so that they can earn sufficient money.

All the results are similar to the most of the previous studies predicting that lower level of per capita GDP, inflation, higher literacy rate and democratic political system leads to terrorism except unemployment which is not predicting terrorism significantly.

\section{Conclusion and Policy Implications}

We can conclude our results by saying this that as it has been obvious from many empirical works that higher literacy rate determines terrorism and explained by this arguments that more the people are educated more the knowledge they can have for making plans or strategies similarly unemployment is not leading terrorism showing that more the people involved in terrorism are employed or experienced. They have better skills used for the implementation of the plans of a terrorist organization. Thus we can say highly educated and employed people can be a part of 


\section{Review of Economics and Development Studies, Vol. 6 (2) 2020, 413-423}

terrorist organization more than illiterate and unemployed.

A terrorist act destroys the infra-structure, people are afraid to move for their work in a terrorized society this results in low production and makes demand greater than supply consequently high inflation rate. Thus we can see that in case of terrorism an economy has to pay economic cost in any form.

We can see whenever there is low Economic growth rate, high inflation rate it will reduce the purchasing power of country men and make them unable to fulfill their basic necessities, in such situation there is a need to provide more employment opportunities to qualified people and those who are already employed need to be provided high salary packages and other social benefits so that they cannot be exploited by terrorist organization. Moreover there is a need to provide more political right to people so that they can convey their problems to their administrators rather than to solve by themselves in wrong ways.

\section{References}

Arciszewski, T., Verlhiac, J. F., Goncalves, I., \& Kruglanski, A. (2009). From psychology of terrorists to psychology of terrorism. Revue internationale de psychologie sociale, 22(3): pp. 5-34.

Barros, C. P. (2003). An intervention analysis of terrorism: The Spanish ETA case. Defence and Peace Economics, 14(6): pp. 401-412.

Barros, C. P., Proenca, I., Faria, J. R., \& Gil-Alana, L. A. (2007). Are USA citizens at risk of terrorism in Europe? Defence and Peace Economics, 18(6): pp.495-507.

Basuchoudhary, A., \& Shughart, W. F. (2010). On ethnic conflict and the origins of transnational terrorism. Defence and Peace Economics, 21(1): pp.65-87.

Basuchoudhary, A., \& Wolliam, F. Shughart III. (2007).On Ethnic Conflict and the Origins of Terrorism. Paper prepared for the Public Choice World Meeting.

Berrebi, C., \& Lakdawalla, D. (2007). How does terrorism risk vary across space and time? An analysis based on the Israeli experience. Defence and Peace Economics, 18(2): pp. 113-131.

Blumberg, H. H. (2002). Understanding and dealing with terrorism: A classification of some contributions from the behavioral and social sciences.

Caruso, R., \& Schneider, F. (2010). Al Qaeda and Jihadist Terrorism in the light of contest theory. A theoretical note and empirical evidence over the period 2002-2007. The Selected Works of Raul Caruso.

Fischer, P., Greitemeyer, T., Kastenmüller, A., Jonas, E., \& Frey, D. (2006). Coping with terrorism: The impact of increased salience of terrorism on mood and self-efficacy of intrinsically religious and nonreligious people. Personality and Social Psychology Bulletin, 32(3): pp. 365-377.

Freytag, A., Krüger, J. J., Meierrieks, D., \& Schneider, F. (2011). The origins of terrorism: Cross-country estimates of socio-economic determinants of terrorism. European Journal of Political Economy, 27:S5-S16.

Fearon, J. D., \& Laitin, D. D. (2003). Ethnicity, insurgency, and civil war. American political science review, 97(1): pp. 75-90.

Hamilton, L. C., \& Hamilton, J. D. (1983). Dynamics of terrorism. International Studies Quarterly, 27(1): pp.39-54. Chicago.

Hoffman, B. (1989). US policy options to the hostage crisis in Lebanon (No. RAND/P-7585). Rand Corp Santamonica CA.

James, K. (2011). The organizational science of disaster/terrorism prevention and response: Theory-building toward the future of the field. Journal of Organizational Behavior, 32(7): 


\section{Review of Economics and Development Studies, Vol. 6 (2) 2020, 413-423}

pp.1013-1032.

Kis-Katos, K., Liebert, H., \& Schulze, G. G. (2011). On the origin of domestic and international terrorism. European Journal of Political Economy, 27: pp.S17-S36.

Krisztina, K., Liebert, H., \& Schulze, G. G. (2011). On the origin of domestic and international terrorism. European Journal of Political Economy, 27: pp. S17-S36.

Krueger, A. B., \& Maleckova, J. (2002). Education, poverty, political violence and terrorism: Is there a causal connection? (No. w9074). National Bureau of Economic Research.

Kurrild-Klitgaard, P., Justesen, M. K., \& Klemmensen, R. (2006). The political economy of freedom, democracy and transnational terrorism. Public Choice, 128(1-2): pp. 289-315.

Murdoch, J. C., \& Sandler, T. (2004). Civil wars and economic growth: Spatial dispersion. American Journal of Political Science, 48(1): pp. 138-151.

Kellner, D. (2004). 9/11, spectacles of terror, and media manipulation: A critique of Jihadist and Bush media politics. Critical Discourse Studies, 1(1): pp. 41-64.

Ismail, A., \& Amjad, S. (2014). Determinants of terrorism in Pakistan: An empirical investigation. Economic Modelling, 37: pp.320-331.

Morselli, C., Giguère, C., \& Petit, K. (2007). The efficiency/security trade-off in criminal networks. Social networks, 29(1): pp.143-153.

Nasir, M., Ali, A., \& Rehman, F. U. (2011). Determinants of terrorism: a panel data analysis of selected South Asian countries. The Singapore Economic Review, 56(o2): pp. 175-187.

Plümper, T., \& Neumayer, E., (2009). International terrorism and the clash of civilizations. British Journal of Political Science, 39(04): pp.711-734.

Quan. L., (2005). Does democracy promote or reduce transnational terrorist incidents?. Journal of Conflict resolution, 49(2): pp. 278-297.

Quan. Li, \& Schaub, D. (2004). Economic globalization and transnational terrorism: A pooled timeseries analysis. Journal of Conflict Resolution, 48(2): pp. 230-258.

Richardson, C. (2011). Relative deprivation theory in terrorism: A study of higher education and unemployment as predictors of terrorism. Politics Department, New sYork University.

Sharma, K. (2006). The political economy of civil war in Nepal. World Development, 34(7): pp. 1237- b bmm./1253. 